Proceedings of the 2018 International Scientific Conference 'Economic Sciences for Agribusiness and Rural Economy' No 2, Warsaw, 7-8 June 2018, pp. 257-263

\title{
QUALITY OF LIFE IN POLISH FARMERS' HOUSEHOLDS ASSESSMENT WITH TOPSIS METHOD
}

\author{
Romana Głowicka-Wołoszyn, $\mathrm{PhD}^{1}$; Andrzej Wołoszyn, $\mathrm{MSc}^{2}$; \\ Feliks Wysocki, Full Professor ${ }^{3}$
}

Faculty of Economics and Social Sciences, Poznań University of Life Sciences

\begin{abstract}
The aim of the research was a multidimensional assessment of the quality of life in farmers' households along with its synthetic measure and a typology of household classes, rendered by the measure. The 2015 data on 730 farmers' households were used to analyse their quality of life in nine dimensions: material living conditions, employment, health, education, leisure and social relations, economic and physical security, civic participation, environmental quality, and the subjective assessment of well-being. Due to concomitance of features measured on metric and non-metric scales, generalized distance measure (GDM) was applied as part of the TOPSIS method to determine the distance of objects from the model values. The study drew on microdata from the Social Diagnosis survey conducted in 2015 by the Council for Social Monitoring, and employed clusterSim R-package for calculations.
\end{abstract}

Keywords: quality of life, class typology, TOPSIS, farmers' households JEL codes: C38, I31

\section{INTRODUCTION}

The concept of the quality of life made its entrance into the economic sciences during the 1960s to broaden and provide a more social perspective to the notion of economic well-being (Panek, 2016). Since then, there have been many studies on the subject, yet not a single universal definition took shape (Borys and Rogala, 2008; Borys, 2015; Panek 2016; Dudek and Szczęsny, 2017). The complex and multifaceted idea has alternatively been identified with prosperity or well-being, defined as a state of contentment, complacency, happiness, or even equated with existential fulfilment, flowing from Maslowian-like self-actualization (Campbell and Converse 1972; Rutkowski 1987; Bywalec and Rudnicki, 1999). However phrased, the study of such a many-sided concept must require an integrated approach that reflect all its objective and subjective aspects (Kasprzyk, 2012; Panek, 2016) - an approach whose application is by no means straightforward. The current scientific discussion on the quality of life, the ongoing process of redefining its meaning, the development of new analysis methods and measuring techniques (Ostasiewicz, 2004; Panek, 2016), all testify to the vitality of the concept, both as a research subject and as a social

${ }^{1}$ Corresponding author: Wojska Polskiego 28, 60-637 Poznań, Poland, roma@up.poznan.pl, +4861 8466185

${ }^{2}$ Corresponding author: Wojska Polskiego 28, 60-637 Poznań, Poland, andrzej.woloszyn@up.poznan.pl, +4861 8466185

${ }^{3}$ Corresponding author: Wojska Polskiego 28, 60-637 Poznań, Poland, wysocki@up.poznan.pl, +4861 8487118 
idea. Yet, the abundance of definitions and quantification proposals has made the task of standardization all the more urgent, as only a common ground operational framework permits reliable monitoring and consistent comparisons between individuals, social groups, regions or countries.

The framework adopted by the Polish Central Statistical Office (GUS) covers 9 dimensions recommended by the European Statistical System. These are: material living conditions (D1), employment (D2), health (D3), education (D4), leisure and social relations (D5), economic and physical security (D6), civic participation (D7), quality of the environment (D8), and subjective assessment of well-being (D9). Correspondent set of measurable indicators developed by GUS forms a tentative, modifiable core that enables in-depth analysis of the individual dimensions. Szukiełojć-Bieńkuńska (2015) draws attention to the particular role of GUS funded cyclical Social Cohesion Survey (BSS) in promoting research on the quality of life in Poland. Editions of the survey were carried in 2011 and 2015 (its last edition just completed) reaching about 15 thousand households. Yet another study on the quality of life in Poland is overseen by the Council for Social Monitoring, as part of bi-annual 'Social Diagnosis' project and includes 8 dimensions: social capital, psychological well-being, physical well-being, social well-being, civilization level, material well-being, stress in life and pathology. In 2015 the survey covered about 12,000 households.

Monitoring the quality of life of various demographic, social and economic groups of households is essential for the implementation and adaptation of public policies oriented towards social inclusion. Farmers' households are one such group, whose material well-being has been progressing steadily in recent years. Their main source of income comes from agricultural activity, still characterized in Poland by a strong link between production and consumption, at least compared to other socio-economic groups. Following Poland's accession to the EU and with subsequent increases in agricultural prices, subsidies, and production volume, the income situation of farmers improved notably (Kozera and Wysocki, 2014). The pace of the growth was higher than in other groups, which translated into narrowing of the income gap that separated the farmers' from the better-off households (Wołoszyn, 2013). Still, despite the recent improvements or more than a decade long operation of cohesion policies, farmers' households continue to exhibit much lower consumption levels, especially as regards durable goods, a fact indicative of lower standards of living (Kozera, Głowicka-Wołoszyn and Stanisławska, 2014).

The aim of the research was a multidimensional assessment of the quality of life in farmers' households in 2015, along with its synthetic measure and a typology of household classes, rendered by the measure.

\section{MATERIALS AND METHODS}

The study drew on microdata from the survey 'Social Diagnosis - the objective and subjective quality of life in Poland', 2015 edition (www.diagnoza.com) conducted by the Council for Social Monitoring (Czapiński and Panek, 2015), that covered 730 Polish farmers' households. The research proceeded in two stages.

- Stage I - Construction of the synthetic index of the quality of life in farmers' households using the TOPSIS method (Hwang and Yoon, 1981; Wysocki, 2010). This stage itself consisted of several steps. First, from among all pure survey questions and tailored indicators (simple features in the parlance of the TOPSIS method) nine sets of features were selected that could be viewed as joint diagnostic measures of the nine quality of life dimensions (in line with the definition adopted by GUS): material living conditions (D1), employment (D2), health (D3), education (D4), leisure and social relations (D5), economic and physical security (D6), civic participation (D7), quality of the environment (D8), and subjective well-being (D9) ${ }^{1}$.

In the second step all simple features that had been

\footnotetext{
${ }^{4}$ These were (D1): previous month net income, meeting household needs with present income, material situation over previous 2 years, share of food and beverages in total expenses, dwelling sharing, sanitary conditions, meeting nutritional needs; (D2): professional skill acquisition over previous 2 years, job satisfaction; (D3): disability, health problems affecting
} 
considered destimulants of the quality of life were transformed into stimulants. Feature normalization followed in the third step. Next, the coordinates of the positive $\left(\mathrm{A}^{+}\right)$and negative $\left(\mathrm{A}_{-}\right)$ideals were taken to be the maximum and minimum values of the features over the set of all $N=730$ objects (households). These coordinates were needed for the fifth step: the calculation of the distance between objects and the ideals.

With a set of features measured on an ordinal scale the Euclidean distance cannot be used as object similarity measure. One solution is to choose the Generalized Distance Measure (GDM) as most universal when dealing with qualitative or mixed-type data. GDM is based on the notion of generalized correlation coefficient that combines Pearson linear and Kendall tau correlation coefficients (Walesiak, 2016). GDM distance of the $i$-th object $(I=1, \ldots, N)$ to the positive ideal $(j=N+1)$ or to the negative ideal $(j=N+2)$ is given by the following formula (Walesiak, 2016):

$$
d_{i j}^{(*)}=\frac{1}{2}-\frac{\sum_{k=1}^{K} a_{i j k} b_{i j k}+\sum_{k=1}^{K} \sum_{l=1}^{N+2} a_{i l k} b_{j l k}}{2\left[\left(\sum_{k=1}^{K} a_{i j k}^{2}+\sum_{k=1}^{K} \sum_{l=1, l \neq i, j}^{N+2} a_{i l k}^{2}\right) \cdot\left(\sum_{k=1}^{K} a_{i j k}^{2}+\sum_{k=1}^{K} \sum_{l=1, l \neq i, j}^{N+2} a_{i l k}^{2}\right)\right]^{\frac{1}{2}}},
$$

where: $I=1, \ldots, N, j=N+1, N+2$, and $\left(^{*}\right)$ denotes either positive or negative ideal.

For ordinal scale, the distance indicator $a(b)$ is calculated in the following way:

$$
a_{i u k}\left(b_{j t k}\right)=\left\{\begin{array}{cc}
1 & x_{i k}>x_{u k}\left(x_{j k}>x_{t k}\right) \\
0 & x_{i k}=x_{u k}\left(x_{j k}=x_{t k}\right) \\
-1 & x_{i k}<x_{u k}\left(x_{j k}<x_{t k}\right)
\end{array}\right.
$$

where: $x_{i k}\left(x_{j k}, x_{l k}, x_{u k}, x_{t k}\right)$ is the $i$-th ( $j$-th, $l$-th, $u$-th, $t$-th) observation on $k$-th feature. For the distance calculations the study employed clusterSim R package.

In step 6 values of the synthetic sub-indices were calculated separately for each of the nine quality of life dimensions $(D=1, \ldots, 9)$ in the usual way of the TOPSIS method:

$$
q_{i}^{D}=\frac{d_{i}^{-}}{d_{i}^{+}+d_{i}^{-}}
$$

where: $0 \leq q_{i}^{D} \leq 1, i=1,2, \ldots, N$

everyday activities, smoking, hospitalization, medical expense decisions due to financial hardship; (D4): household head's educational attainment, foreign language competence, internet access, type of internet connection, computer use; (D5): culture related decisions due to financial hardship, book collection at home, meeting culture related needs, leisure related decisions due to financial hardship, satisfaction of leisure needs over previous 2 years, leisure satisfaction; (D6): home insurance, outstanding housing, gas and energy bills, mortgage debt, other debts, emergency fund to cover unexpected expenses, crime and safety concerns, security satisfaction in the place of residence; (D7): support for local government, commitment to the local community, voting in elections, membership in organizations, participation in public meetings; (D8): overcrowding, problems with annoying neighbours, satisfaction with recreational areas; (D9): general life assessment, recent stocktaking, last year evaluation. 
Finally, the joint synthetic index of the quality of life $\left(Q_{i}\right)$ was calculated as the average of the synthetic sub-indices from the nine dimensions $\left(Q_{i}=\sum_{D=1}^{9} q_{i}^{D}\right)$. Then, four distinct typological classes of the quality of life were established, based on the mean $\left(Q_{a v}\right)$ and standard deviation $\left(S_{Q}\right)$ of the synthetic index $Q_{i}$ :

- class I (high): $Q_{i} \geq Q_{a v}+S_{Q}$,

- class II (medium high): $Q_{a v} \leq Q_{i}<Q_{a v}+S_{Q}$,

- class III (medium low): $Q_{a v}-S_{Q} \leq Q_{i}<Q_{a v}$,

- class IV (low): $Q_{i}<Q_{a v}-S_{Q}$.

- Stage II - Characterization of the quality-of-life typological classes. At this stage the classes were characterized by dimension-specific synthetic sub-indices of the quality of life. Also, some additional household factors were identified that might possibly influence the level of the quality of life among the farmers' households.

\section{RESULTS}

The TOPSIS method employed in the study divided the group of farmers' households into four classes of high (I), medium-high (II), medium-low (III) and low (IV) quality of life, that constituted respectively 15.2, $36,33.9$, and $14.9 \%$ of the total (Table 1). The average sub-index values for each individual dimension were without exception smaller in lower quality of life classes. In class I of high quality of life the values were largest, and very similar to each other, their coefficient of variation was just $7.7 \%$. Descending down to lower quality of life classes all sub-indices were falling but their variability rising, and in class IV the coefficient of variation among sub-indices for the nine dimensions registered $31 \%$.

High ratings of quality of life dimensions in class I were even but not identical: health (D3) scored the highest 0.793 followed by employment (D2) 0.782 and environment (D8) 0.776 . The lowest rating of 0.619 in this class was given to civic participation (D7), with education (D4) and leisure/social relations (D5) slightly higher (0.686 and 0.691, respectively). The most numerous class II of medium-high quality of life showed high scores for all dimensions except D4 and D7, that can be described as average. The ranking of dimensions in this class gave preference to health (D3 - 0.698), followed by D8 (0.631) and D2 (0.625). Class III of medium low quality of life also scored high on health (D3 - 0.682) and roughly mirrored the ranking of class II, albeit with middling 0.531 and 0.509 values for D8 and D6 (environment and economic/physical security), respectively. The only notable exception was employment (D2) that plunged to the last position with a low rating of 0.398 . The low quality of life class IV was characterized by middling levels of D8 (0.498), D3 (0.494) and D6 (0.452), a very low rating of D7 (0.157) and rather low remaining ratings.

Analysing the quality of life by dimensions rather than classes, one can notice that health (D3) ranked first in classes I-III and second in class IV. Environment (D8) followed second and third in the higher three classes and came first in class IV. In all the classes a consistently low, penultimate place was accorded to education (D4), due perhaps to its purely objective character. Interestingly, employment (D2), that remained high in the ranking of classes I and II, came last in III and IV. The position of this dimension most strikingly set apart the high from the low quality of life classes.

Continuing beyond the quality of life dimensions, the study examined compositions of the four classes by demographic and social characteristics such as household size or head's age and education to find possible determinants of the quality of life in farmers' households. Its higher levels were found to correspond to higher fractions of households run by persons with at least secondary education (class IV: $4.7 \%$, III: $15.4 \%$, II: 39.4\%, I: $60.8 \%$ ). Furthermore, households with high quality of life (I) were headed by persons of average age 45.8 years, ten years younger than those with low quality (IV). The two classes also differed in fractions of small and medium-size households: in class I the 1- and 2-person households (of typically older members) accounted for less than $10 \%$, while in class IV for as much as $34.2 \%$ of their respective compositions. At the same time the fraction of 3- and 4-person households in class I was $53 \%$, while in class IV - about $29 \%$. All in all, farmers' households with higher quality of life were better educated, younger and more likely had children (but not too many). 
Table 1. Quality of life classification results for farmers' households in Poland in 2015

\begin{tabular}{|c|c|c|c|c|c|c|c|c|c|c|}
\hline \multirow{2}{*}{\multicolumn{2}{|c|}{ Specification }} & \multicolumn{8}{|c|}{ Typological class } & \multirow{3}{*}{ Overall } \\
\hline & & \multicolumn{2}{|c|}{ I } & \multicolumn{2}{|c|}{ II } & \multicolumn{2}{|c|}{ III } & \multicolumn{2}{|c|}{ IV } & \\
\hline \multicolumn{2}{|c|}{ Quality of life level } & \multicolumn{2}{|c|}{ high } & \multicolumn{2}{|c|}{ medium high } & \multicolumn{2}{|c|}{ medium low } & \multicolumn{2}{|c|}{ low } & \\
\hline \multicolumn{2}{|c|}{ Synthetic (sub)-index } & \multicolumn{2}{|c|}{$\langle 0.669 ; 0.826\rangle$} & \multicolumn{2}{|c|}{$\langle 0.550 ; 0.669)$} & \multicolumn{2}{|c|}{$\langle 0.432 ; 0.550)$} & \multicolumn{2}{|c|}{$\langle 0.194 ; 0.432)$} & $\langle 0.194 ; 0.826\rangle$ \\
\hline \multirow{2}{*}{$\begin{array}{l}\text { Farmers' } \\
\text { households }\end{array}$} & number & \multicolumn{2}{|c|}{111} & \multicolumn{2}{|c|}{263} & \multicolumn{2}{|c|}{247} & \multicolumn{2}{|c|}{109} & 730 \\
\hline & share $(\%)$ & \multicolumn{2}{|c|}{15.2} & \multicolumn{2}{|c|}{36.0} & \multicolumn{2}{|c|}{33.9} & & & 100 \\
\hline & & D3 & 0.793 & D3 & 0.698 & D3 & 0.682 & D8 & 0.498 & D1 $0.037 ; 0.985$ \\
\hline & & D2 & 0.782 & D8 & 0.631 & D8 & 0.531 & D3 & 0.494 & D2 $0.000 ; 1.000$ \\
\hline & & D8 & 0.776 & D2 & 0.625 & D6 & 0.509 & D6 & 0.452 & D3 $0.013 ; 1.000$ \\
\hline & & D6 & 0.747 & D9 & 0.613 & D1 & 0.495 & D7 & 0.395 & D4 0.000; 1.000 \\
\hline Dimension 1 & Inking & D9 & 0.745 & D1 & 0.612 & D9 & 0.462 & D1 & 0.341 & D5 0.028; 0.963 \\
\hline synthetic su & -indices & D1 & 0.711 & D5 & 0.611 & D5 & 0.459 & D5 & 0.334 & D6 0.136; 1.000 \\
\hline & & D5 & 0.691 & D6 & 0.609 & D7 & 0.456 & D9 & 0.297 & D7 0.000; 1.000 \\
\hline & & D4 & 0.686 & D4 & 0.573 & D4 & 0.445 & D4 & 0.274 & D8 $0.000 ; 1.000$ \\
\hline & & D7 & 0.619 & D7 & 0.508 & D2 & 0.398 & D2 & 0.157 & D9 $0.000 ; 1.000$ \\
\hline & & & & ograp & and soc & deter & nants & & & \\
\hline Quality of li & e level & & & med & $n$ high & med & n low & & & Overall \\
\hline & & Househ & d head's & lucatic & l attainr & nt $(\%$ & farmers' & ouseholc & & \\
\hline Elementary & r none & & & & & & & & & 15.7 \\
\hline $\begin{array}{l}\text { Basic vocat } \\
\text { Junior high }\end{array}$ & nal or & & & & & & & & & 55.0 \\
\hline Secondary & & & & & & & & & & 24.6 \\
\hline Higher & & & & & & & & & & 4.8 \\
\hline Total & & & & & & & & & & 100.0 \\
\hline & & & Hous & old si & $(\%$ of fa & ers' hc & eholds) & & & \\
\hline 1 & & & & & & & & & & 6.32 \\
\hline 2 & & & & & & & & & & 12.94 \\
\hline 3 & & & & & & & & & & 16.37 \\
\hline 4 & & & & & & & & & & 21.59 \\
\hline 5 & & & & & & & & & & 15.72 \\
\hline $6+$ & & & & & & & & & & 27.06 \\
\hline Total & & & & & & & & & & 100.0 \\
\hline & & & Sex of ho & sehold & $\mathrm{ead}(\%$ & farmer & househo & & & \\
\hline Female & & & & & & & & & & 10.6 \\
\hline Male & & & & & & & & & & 89.4 \\
\hline Total & & & & & & & & & & 100.0 \\
\hline & & & & ge of & usehold & $\mathrm{ead}(\mathrm{ye}$ & & & & \\
\hline Age & & & & & & & & & & 49.9 \\
\hline
\end{tabular}

Source: own elaboration based on microdata from Social Diagnosis 2015 survey (Retrieved from: http//diagnoza.com, accessed 15.03.2017). 


\section{CONCLUSIONS}

Employment of the TOPSIS method with general distance measure GDM permitted multidimensional assessment of the quality of life in farmers' households in 2015. The presented research method can be used in public policy implementations to diagnose the quality of life of specific social groups and the typologies of those groups. This would help to identify factors contributing to the improvement of the quality of life, better target social policy and strengthen support for groups of households with low quality of life.

Analysis of nine quality of life dimensions, overall and for the four classes, helped create profiles of farmers' households with different quality of life levels. The values of dimension specific synthetic sub-indices were high in the first class, high and medium in the second, medium in the third and low in the fourth class. Their ranking however was not the same in every class. Health and environment were ranked everywhere high, education everywhere low, but employment was high in the higher classes and low in the lower ones. A rather heterogeneous dimension of economic and physical security occupied further places in the rankings of higher classes, but were relatively high up in the lower ones.

Demographic and social composition of the households was also found to differ markedly, especially between classes I and IV. In the former, most (61\%) households had heads with at least secondary education, their average age was 46 years, and were mostly (53\%) comprised of 3 or 4 persons. The households in class IV were mostly ( $95 \%$ ) headed by persons with at best basic vocational education, with average age of 55 years, and had mostly (58\%) either very few ( 1 or 2$)$ or very many (6 or more) members.

\section{REFERENCES}

1. Borys, T. (2015). Typologia jakości życia i pomiar statystyczny [Typology of Life Quality and Statistical Measurement]. Wiadomości Statystyczne, 7, pp. 1-18.

2. Borys, T., Rogala, P. (ed.) (2008). Quality of life on local level - an indicators - based study. UNDP, Warszawa.
3. Bywalec, C., Rudnicki L. (1999). Podstawy ekonomiki konsumpcji [Basics of consumer economics]. Wydawnictwo Akademii Ekonomicznej w Krakowie, Kraków.

4. Campbell, A., Converse, P.E. (1972). The human meaning of social change. Russell Sage Foundation, New York.

5. Czapiński, J., Panek T. (ed.) (2015). Diagnoza Społeczna - Warunki i jakość życia Polaków [Social Diagnosis - the objective and subjective quality of life in Poland]. Rada Monitoringu Społecznego, Warszawa. Retrieved from: http//diagnoza.com [Accessed 15.03.2017].

6. Dudek, H., Szczęsny, W. (2017). Correlates of Multidimensional Indicator of Quality of Life - Fractional Outcome Model Approach. Statistika: Statistics and Economy Journal, 97 (4), pp. 46-61.

7. Hwang, C.L., Yoon, K. (1981). Multiple attribute decision making. Methods and applications. Springer, Berlin.

8. Kasprzyk, B. (2012). Subiektywizm ocen dobrobytu ekonomicznego (na przykładzie gospodarstw domowych w regionie podkarpackim) [The Subjective Opinions of Welfare in the Households in the Podkarpacie Region]. Nierówności Społeczne a Wzrost Gospodarczy, 25, pp. 191-201.

9. Kozera, A., Głowicka-Wołoszyn, R., Stanisławska, J. (2014). Niedobory konsumpcji w gospodarstwach domowych rolników po wstapieniu Polski do Unii Europejskiej [Consumption deprivation in farmer's households in the context of polish accession to European Union]. Roczniki Naukowe SERiA, 16 (6), pp. 274-280 .

10. Kozera, A., Wysocki, F. (2014). Sytuacja finansowa gospodarstw domowych rolników na tle pozostałych grup społeczno-ekonomicznych ludności [Financial situation of households of farmers against the background of other socio-economic groups of the population]. Journal of Agribusiness and Rural Development, 3 ( 33), pp. 85-99.

11. Ostasiewicz, W. (ed). (2004). Ocena i analiza jakości życia [Assessment and analysis of the quality of life]. Wydawnictwo Akademii Ekonomicznej im. Oskara Langego we Wrocławiu, Wrocław.

12. Panek, T. (2016). Jakość życia. Od koncepcji do pomiaru [Quality of life. From conception to measurement]. Oficyna Wydawnicza SGH, Warszawa.

13. Szukiełojć-Bieńkuńska, A. (2015). Pomiar jakości życia w statystyce publicznej [Measurement of Life Quality in Official Statistics]. Wiadomości Statystyczne, 7, pp. 19-32. 
Proceedings of the 2018 International Scientific Conference 'Economic Sciences for Agribusiness and Rural Economy' No 2, Warsaw, 7-8 June 2018, pp. 257-263

14. Walesiak, M. (2016). Uogólniona miara odległości GDM w statystycznej analizie wielowymiarowej z wykorzystaniem programu R [Generalized GDM distance measure in a statistical multivariate analysis using the R program]. Wydawnictwo Uniwersytetu Ekonomicznego we Wrocławiu, Wrocław.

15. Wołoszyn, A. (2013). Nierówności dochodowe w gospodarstwach domowych rolników na tle innych grup społeczno-ekonomicznych w Polsce w latach 2005 i 2010
[Income inequality among farmer households against other socio-economic groups in Poland in 2005 and 2010]. Roczniki Naukowe SERiA, 15 (6), pp. 313-319.

16. Wysocki, F. (2010). Metody taksonomiczne w rozpoznawaniu typów ekonomicznych rolnictwa i obszarów wiejskich [The methods of taxonomy for recognition of economic types in agriculture and rural areas] Wydawnictwo Uniwersytetu Przyrodniczego w Poznaniu, Poznań. 